Anita Wincencjusz-Patyna

Akademia Sztuk Pięknych im. Eugeniusza Gepperta we Wrocławiu

\title{
Ingrid Vang Nyman i Pippi Pończoszanka, czyli o Pippi - dziecięcej rebeliantce - i Pus - duńskiej artystce, która dokonała rewolucji w szwedzkiej książce dla dzieci
}

Ingrid Vang Nyman and Pippi Longstocking, or on Pippi - a child rebel - and Pus the Danish artist who staged a revolution in Swedish children's books

This article focuses on Ingrid Vang Nyman's illustrations to various books about Pippi Longstocking, written by Astrid Lindgren, ranging from novels through picturebooks to comics. The core of the paper is an analysis of the Danish artist's style, her use of means of artistic expression, and her attitude towards avant-garde movements in Western art in the 1930s and 1940s. The text briefly covers Vang Nyman's biography, and the influence of her Danish background, taking mainly the period of her studies at the Royal Academy of Fine Arts in Copenhagen into consideration. Analysis makes it possible to indicate three main features of Vang Nyman's "Pippi works", which are a specific construction of space, anti-classical aesthetics, and a selfdiscilplined use of basic colours taken from modern painting, e.g. Neo-Plasticism.

Key words: Pippi Longstocking, Ingrid Vang Nyman, Astrid Lindgren, modern book illustration, Scandinavian picture books

Słowa klucze: Pippi Pończoszanka, Ingrid Vang Nyman, Astrid Lindgren, modernistyczna ilustracja książkowa, skandynawska książka obrazkowa

Postać ognistej z wyglądu i charakteru dziewczynki, zamieszkującej bez rodziców chwiejącą się w posadach willę, w zbiorowej wyobraźni polskiego odbiorcy miała szansę zaistnieć na początku lat 60. XX wieku. W 1961 roku ukazało się bowiem ilustrowane czarno-białymi rysunkami Zbigniewa Piotrowskiego pierwsze w Polsce wydanie książkowe przygód tej bez wątpienia najlepiej znanej postaci w dorobku Astrid Lindgren (Lindgren 1961) ${ }^{1}$. Z kolei w następnej dekadzie rezolutna

Polscy czytelnicy mieli szansę poznać już wtedy Dzieci z Bullerbyn (1957), Nilsa Paluszka (1958), Karlssona z dachu (1959a) oraz Rasmusa i włóczęgę (1959b). W Szwecji Pippi Långstrump 
dziewięciolatka nabrała barw i życia za sprawą filmowej koprodukcji szwedzko-niemieckiej (Pippi Langstrumpf 1969), emitowanej u nas z polskim dubbingiem od 1974 roku. I w Szwecji, i w Polsce, a właściwie na całym świecie (Kümmerling-Meibauer i Surmatz 2011) postać Pippi urosła do rangi symbolu, a spośród wszystkich innych bohaterów utworów Lindgren to właśnie jej poświęcono zdecydowanie największą liczbę opracowań, zarówno o charakterze akademickim, jak i tych w ujęciu bardziej popularno-naukowym². Na przykład dla literaturoznawczyń z Uniwersytetu Śląskiego w Katowicach jest Pippi „[...] s y m b o le m literatury dla dzieci [wyróżnienie - A.W.-P.] - idącej pod prąd oczekiwań i przyzwyczajeń dorosłych, łagodzącej humorem i absurdem egzystencjalne lęki, promującej radość życia dzieloną z drugim człowiekiem" (Gralewicz-Wolny i Mytych-Forajter 2013: 8). Hanna Dymel-Trzebiatowska jej miejsce w literaturze światowej widzi obok Alicji w Krainie Czarów, Piotrusia Pana, Kubusia Puchatka i Muminków (Dymel-Trzebiatowska 2018: 203). W Szwecji od dawna (w innych krajach nastąpiło to trochę później) jest uznawana za symbol feminizmu, a w specyficznych realiach PRL-u postawę zbuntowanego, przekornego rudzielca chętnie odczytywano jako przejaw nonkonformizmu wobec władzy (Murzynowska 2007).

Pippi wymyka się jednoznacznym interpretacjom podejmowanym przez badaczy z przeróżnych perspektyw - od pedagogicznych ${ }^{3}$, przez filozoficzno-antropologiczne (Gaare i Sjaastad 2002), po feministyczne (Shevah 2015), genderowe (Murzynowska 2007) i queerowe (Söderberg 2010). Cały ten wachlarz bez wątpienia niewyczerpanych możliwości analitycznych i interpretacyjnych sprowadzony do polskiego obszaru refleksji można odnaleźć w wielowątkowym opracowaniu Doroty Murzynowskiej Pippi Pończoszanka w polskim dyskursie kulturowym (Murzynowska 2007). Kolejne tropy w ujęciu międzynarodowym zostały zebrane w tomie poświęconym twórczości Lindgren (w którym uwagę teoretyków zajęły także inne książki szwedzkiej autorki) Beyond Pippi Longstocking. Intermedial and international aspects of Astrid Lindgren's works (Kümmerling-Meibauer i Surmatz 2011). Te tak różnorodne spojrzenia potwierdzają jedynie złożoność i wielowymiarowość postaci wykreowanej przez Lindgren w 1941 roku z niepoślednim udziałem córki Karin (Bąk 1986: 2). Do szerokiej publiczności Pippi dotarła wraz z pierwszym szwedzkim wydaniem książkowym w 1945 roku. Jak słusznie zauważa Beata Mytych-Forajter, autorka tekstu zatytułowanego Uwolnić Pippi!: „Oto bowiem ruda,

ukazała się drukiem w 1945 r., krótko po tym, jak Lindgren zadebiutowała książką Britt-Mari lättar sitt hjärta (1944); polskie wydanie pt. Zwierzenia Britt-Mari ukazało się w 1962 r. Por. Tylicka i Leszczyński (2002: 220).

2 Wybór tych opracowań zamieszczono na końcu artykułu w literaturze przedmiotu.

3 O wpływie pism pedagogicznych Bertranda Russella i świadomości istnienia pedagogiki alternatywnej Alexandra Sutherlanda Neilla Lindgren wspominała w wywiadzie udzielonym Krzysztofowi Bąkowi (Bąk 1986); por. także Hallberg (2001: 26-44), gdzie znajdziemy analizę postaci Pippi z perspektywy idei pedagogicznych w Danii i Szwecji w latach 30. i 40. XX w. 
piegowata, pyskata, najsilniejsza na świecie dziewczynka sprytnie unika każdej próby usidlenia, czyli w jakiejś mierze sprowadzenia jej do tego, co znane, gładkie i jednoznaczne, nawet jeśli źródłowo wywrotowe" (Mytych-Forajter 2016: 11).

Wygląd fizyczny Pippi jest doskonałą emanacją jej osobowości i zachowania. Jak trafnie skonstatowała cytowana wyżej literaturoznawczyni: „Kontakt z nią «parzy», jak kolor włosów, którymi została obdarzona. Pippi płonie bowiem, detonując powagę i tzw. autorytety. Jest czcicielką ognia, figury wiecznej zmiany, wobec którego zachowuje się jak ogarnięta piromańską pasją czarodziejka lub szamanka" (Mytych-Forajter 2016: 12). Przy takim potencjale siły rażenia dynamitu trudno oprzeć się magnetyzmowi tego najdziwniejszego dziecka, jak sama określała Pippi jej literacka matka - Astrid Lindgren (Strömstedt 2006: 118).

Niejednoznaczność Pippi dobrze oddają jej polskie dzieje. Czytelnicy z kraju nad Wisłą poznali ją bowiem najpierw jako Fizię Pończoszankę, podążając za wydanym nakładem Naszej Księgarni (16 lat po premierowej edycji w Szwecji) tłumaczeniem Ireny Szuch-Wyszomirskiej. Po kilkunastu latach polska publiczność zakochała się już w Pippi Langstrumpf ${ }^{5}$ (a tak naprawdę w odtwarzającej tytułową postać dziecięcej aktorce Inger Nilsson z głosem znakomitej Ewy Złotowskiej), bo takie właśnie imię pojawiało się w czołówce 13-odcinkowego serialu w reżyserii Ollego Hellboma, ze scenariuszem samej Lindgren (Pippi Langstrumpf 1969). Do 1990 roku w polskich księgarniach królowała Fizia ${ }^{6}$, ale siła oddziaływania i magnetyzm ruchomego obrazu produkcji zachodniej, zwłaszcza w tamtym czasie, sprawiły, że jednak coraz częściej i dla coraz większej grupy odbiorców siłaczka dźwigająca konia była już po prostu Pippi. Nic dziwnego, że ukazujące się od 1992 roku edycje Naszej Księgarni ${ }^{7}$ czy też w obecnym stuleciu (od 2007 r.) poznańskich Zakamarków operują zgrabną hybrydą germańsko-słowiańską, czyli używają imienia Pippi Pończoszanka.

Artykuł ten poświęcony jest jednak stronie graficznej przygód Pippi autorstwa duńskiej artystki Ingrid Vang Nyman, o której dorobku w polskim piśmiennictwie trudno znaleźć dłuższe wypowiedzi. Wyjątkami są passusy dotyczące jej sylwetki w haśle o pierwszym wydaniu Känner du Pippi Långstrump? (Czy znasz Pippi

$4 \quad$ Należy podkreślić, że przekład ten, w porównaniu z translacjami na inne języki, uchodzi za jeden z bardziej wiernych oryginałowi (Teodorowicz-Helmann 1997: 132-135).

5 Niemieckie brzmienie „nazwiska” Pippi jest bardzo zbliżone do szwedzkiego oryginału „Långstrump”. W dosłownym tłumaczeniu jest to Pippi Długa-Pończocha/Skarpeta.

6 Kolejne wydania ukazywały się w 1970, 1982 i 1990 r. W 1984 r. Nasza Księgarnia po raz pierwszy wydała dwa pozostałe tomy trylogii: Fizia Pończoszanka wchodzi na pokład oraz Fizia Pończoszanka na Południowym Pacyfiku, tym razem w tłumaczeniu Teresy Chłapowskiej (wyd. 2. obu książek w 1990 r.).

Por. Pippi Pończoszanka wydawana od 1992 r. co rok lub co dwa lata, Przygody Pippi Pończoszanki (2011, 2016, 2017, 2020 r.) w przekładach Ireny Szuch-Wyszomirskiej oraz Teresy Chłapowskiej. 
Pończoszankę?) z leksykonu Ksią̇̇ka obrazkowa (Dymel-Trzebiatowska 2018: 203-207) oraz fragmenty artykułu poświęconego skandynawskiej ilustracji książki dla dzieci Nie tylko Muminki (Wincencjusz-Patyna 2011: 73-75). Wydania z jej ilustracjami zaczęły ukazywać się na polskim rynku dopiero od 1992 roku, kiedy to Nasza Księgarnia opublikowała opowiadanie zatytułowane Zabawa choinkowa

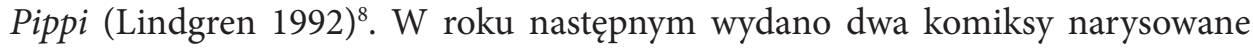
przez Vang Nyman (Lindgren i Vang Nyman 1993a i 1993b)์. Od tego momentu Nasza Księgarnia dość zdecydowanie oddała duńskiej ilustratorce warstwę obrazową książek o perypetiach najsilniejszej buntowniczki świata ${ }^{10}$. Zakamarki, skupiając się na książkach obrazkowych o Pippi, niejako w naturalny sposób wydawały kolejne pozycje jako integralne całości ikonotekstowe (Lindgren 2007, 2008; Lindgren i Vang Nyman 2015, 2016, 2020).

Choć Vang Nyman ma na koncie ilustracje do około czterdziestu książek, kilkanaście zrealizowanych okładek i niezliczone ilustracje do prasy dziecięcej, a także projekty grafiki reklamowej i plakaty ${ }^{11}$, najbardziej rozpoznawalna pozostaje dzięki ilustracjom do utworów Astrid Lindgren, a zwłaszcza do książek o Pippi (Törnqvist 2016: 81). Wśród nich szczególna rola przypisywana jest ilustracjom do pierwszego wydania Pippi Långstrump. Zostały one uznane za klasykę tego rodzaju twórczości, a jednocześnie w ocenie badaczy wyznaczają początek nowoczesności w szwedzkiej ilustracji dla dzieci (Druker 2013: 103-115). Co ważne, sami artyści zajmujący się współcześnie w Szwecji tą dziedziną twórczości uznają wagę i wpływ dokonań Vang Nyman w okresie powojennym. Dostrzegają jej kluczową rolę w otwarciu szwedzkiej ilustracji na awangardowe poszukiwania i nowe prądy w sztuce, co okazało się oddziaływaniem długofalowym. Doskonałym zobrazowaniem tego zjawiska jest publikacja Vår Pippi - Vår Vang. Tecknarna hyllar Ingrid Vang Nyman och det moderna genombrottet inom svensk barnboksbild (Nasza Pippi - nasza Vang. Ilustratorzy w hołdzie Ingrid Vang Nyman i modernistycznemu przełomowi w szwedzkiej ilustracji książkowej dla dzieci), pod redakcją Ulli Rhedin i Gunny Grähs (2016), wydana z okazji 100-lecia urodzin ilustratorki Pippi.

Ingrid Vang Lauridsen urodziła się 21 sierpnia 1916 roku w duńskim Vejen w południowej Jutlandii jako pierwsza z trzech córek Helgi i Pedera. Nazywano ją

8 Do 1990 r. tom pierwszy trylogii ukazywał się z ilustracjami Zbigniewa Piotrowskiego, a drugi i trzeci w opracowaniu graficznym Anny Kołakowskiej.

9 Pippi urzadza przyjęcie (Lindgren 1993b) oraz Pippi jest najsilniejsza na świecie (Lindgren 1993a). Za zwrócenie mi uwagi na te wydania bardzo dziękuję Agnieszce Stróżyk.

10 Wyjątkiem jest reprint pierwszego polskiego wydania z ilustracjami Piotrowskiego, który Nasza Księgarnia wypuściła na rynek w 2015 r. jako wydanie kolekcjonerskie pod tytułem Pippi Pończoszanka.

11 Pełen wykaz dokonań ilustratorskich i innych realizacji z obszaru grafiki projektowej Vang Nyman zamieszczony został jako aneks do biografii artystki (Törnqvist 2016: 149-166). 
w domu Pus (duń. 'skarb, kochanie' stosowane wobec dziecka). W 1935 roku rozpoczęła studia na kopenhaskiej uczelni artystycznej, którą jednak porzuciła, niezadowolona z przebiegu studiów. Poznała tam swojego przyszłego męża, malarza i rysownika Arnego Nymana. Para wzięła ślub w 1940 roku; w tym samym roku przyszedł na świat ich syn Peder, dla domowników Pelle. Małżeństwo wkrótce się rozpadło. W 1943 roku samotna matka przeniosła się z synem do Sztokholmu. To tam zaczęła się główna praca zarobkowa Ingrid - ilustrowanie czasopism i książek dla dzieci. W 1954 roku artystka wróciła do Kopenhagi. Nie mogąc się uporać z chorobami wyniszczającymi jej umysł i ciało, Vang Nyman zakończyła swe pełne cierpienia życie samobójczą śmiercią. Zmarła w Kopenhadze 13 grudnia 1959 roku.

Od najmłodszych Ingrid lat była zachęcana przez swoich wykształconych rodziców do indywidualnej nauki. Oczytana, rozbudzona intelektualnie i uzdolniona plastycznie dość wcześnie ujawniła talent do rysowania. Nic zatem dziwnego, że jeszcze jako bardzo młoda dziewczyna podjęła decyzję o studiach w kopenhaskiej Duńskiej Królewskiej Akademii Sztuk Pięknych, poprzedzonych uczestnictwem w kursie przygotowawczym. W tym okresie najbardziej zajmowały ją studia postaci i portrety. W obrazach z przełomu lat 30. i 40. XX wieku widoczna jest fascynacja twórczością postimpresjonistów, zwłaszcza Paula Cézanne’a i Paula Gauguina, w świadomym podkreślaniu konturu oraz w sposobie kładzenia i w doborze kolorów. Dostrzegalne w tych pracach są także pewne związki z fowizmem i malarstwem Amadeo Modiglianiego. Powszechne w ówczesnej Europie zapatrzenie artystów na dokonania grafiki dalekowschodniej, zwłaszcza drzeworytów japońskich, przełoży się na idące pod prąd tradycji zachodniej odmienne ujmowanie przestrzeni, przekładanie relacji trójwymiarowych na płaską powierzchnię podobrazia czy kartki papieru, na której będą powstawać rysunki młodej artystki. Predylekcja do operowania wyrazistym konturem jest jedną z cech charakteryzujących jej dokonania także w późniejszym okresie, kiedy będzie aktywna głównie na polu grafiki projektowej - ilustracji do książek i czasopism. Kontynuacją poszukiwań z czasu studiów będzie także śmiałe operowanie kolorem, natomiast jako rysowniczka wyczyści swe prace z jakiegokolwiek modelunku światłocieniowego. Kilka lat studiów na akademii, mimo otwarcia samej instytucji i ówczesnej sztuki duńskiej na postawy i tendencje awangardowe, przyniosło jej więcej rozczarowań niż sukcesów. Podobnie małżeństwo, którego fiasko przypieczętował wyjazd z synkiem do Sztokholmu w 1943 roku.

Kolejny rok okazał się przełomowy dla kariery i przyszłości dwóch kobiet, które niebawem, i to jakże brzemiennie w skutki, połączy Pippi. Lindgren zadebiutowała właśnie wtedy Zwierzeniami Britt-Mari, a Vang Nyman ilustracjami do opowiadania o małym Eskimosie, wydrukowanego w grudniowym numerze dziennika Dagens Nyheter. Przed Pippi Dunka zrealizowała jeszcze kolejne zamó- 
wienia dla tego wiodącego szwedzkiego dziennika oraz dla następujących tytułów prasowych: Folkskolans Barntidning, Husmodern i Joker. Premierę najsłynniejszej książki w dorobku obu pań poprzedziły w przypadku Vang Nyman ilustracje do Ivik den faderlöse (Ivik, chłopiec bez ojca) autorstwa Pipaluk Freuchen (1945) oraz do zbioru opowiadań Barnens önskebok (Dziecięca księga życzeń) (1945). Do realizacji szaty graficznej Pippi Långstrump Vang Nyman przystąpiła w sierpniu 1945 roku jako zwyciężczyni konkursu na ilustracje ogłoszonego przez sztokholmskie wydawnictwo Rabén \& Sjögren. Książka miała ukazać się przed świętami Bożego Narodzenia, a zatem artystka nie miała do dyspozycji zbyt wiele czasu na przygotowanie całości. Kluczowa była okładka, na której musiał pojawić się atrakcyjny portret głównej bohaterki (il. 1).

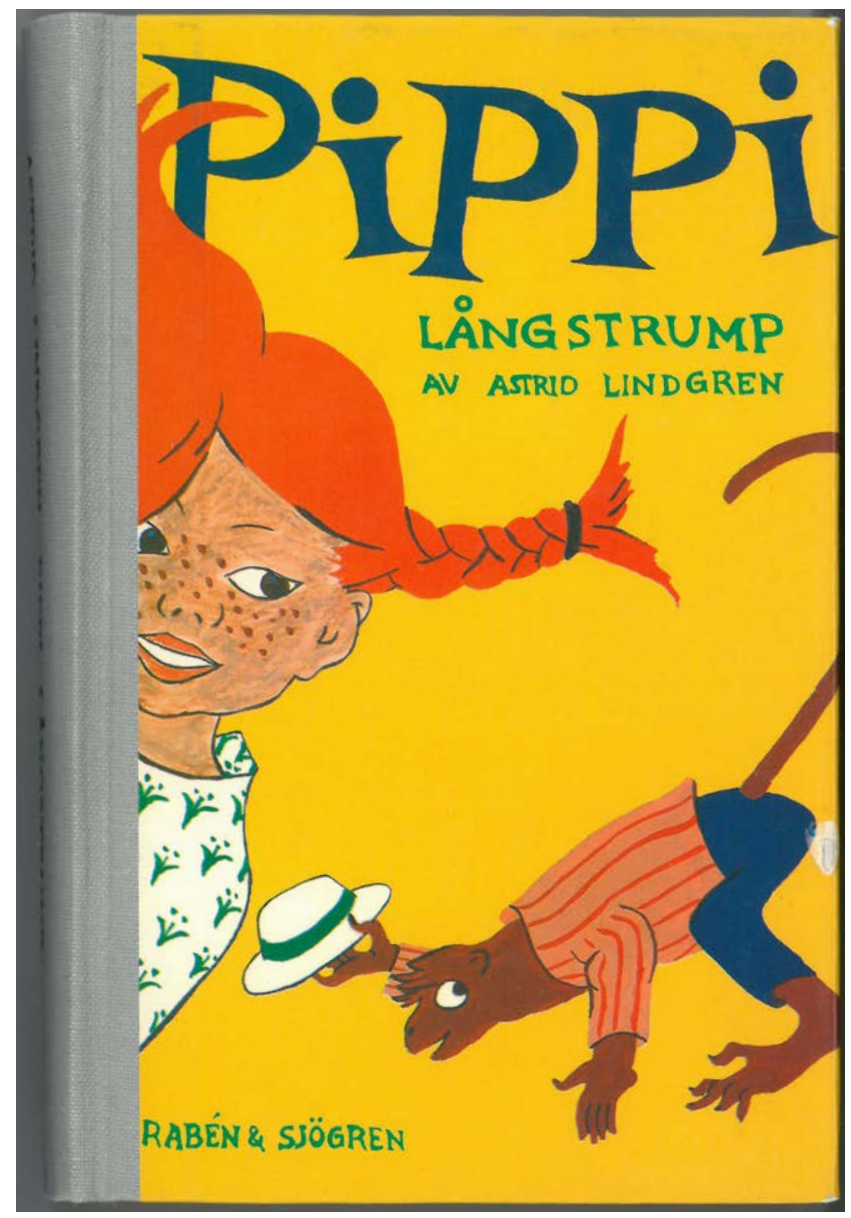

Ilustracja 1. Okładka pierwszego wydania szwedzkiego Pippi Långstrump wydawnictwa Rabén \& Sjögren. @Ingrid Vang Nyman, The Astrid Lindgren Company Źródło: Lindgren (1945). 
Dunka wykonała go wedle bardzo szczegółowego opisu Lindgren, która podkreśliła najważniejsze cechy Pippi: ognistorude włosy, liczne piegi i bystre spojrzenie (Törnqvist 2016: 79). Jaskrawe kolory doskonale rozgrywające triadę barw podstawowych - zbliżone do czerwieni włosy, błękit wersalików imienia Pippi w dużym tytule książki i porteczek Pana Nilssona (makaka - małpki-towarzyszki Pippi) oraz żółć tła - zwracały uwagę w równym stopniu, co intrygująca, otwarta kompozycja z bardzo śmiałym kadrem obcinającym sylwetki bohaterów przedstawienia. Pippi sprawia wrażenie wychylającej się jakby zza węgła - widać tylko jej głowę (bez prawego warkocza) i lewe ramię; dynamicznie wygięty ogon małpki także „nie zmieścił się” w całości. Ta okładka w pełni zapowiadała nowatorskie na gruncie szwedzkim podejście do wizualnej strony książki dziecięcej. Niezdyscyplinowana - na podobieństwo głównej bohaterki - łamała schematy ugrzecznionych, eleganckich, sięgających tradycji zanurzonej jeszcze w XIX wieku ilustracji autorstwa Ann-Sofi Schotte, Norweżki Marie Walle, a przede wszystkim gwiazdy szwedzkiej książki dla dzieci - Elsy Beskow. Można było odnieść wrażenie, że Beskow na dobre ukształtowała gust odbiorców książki obrazkowej w swojej ojczyźnie dzięki idyllicznym sceneriom dekoracyjnie traktowanej przyrody, ślicznym twarzyczkom swoich postaci, zawsze schludnie odzianych i grzecznych, przenosząc do Skandynawii idee wiktoriańskiej book beautiful i secesyjnej ornamentyki. Cała szata graficzna, podobnie zresztą jak i tekst Pippi Långstrump, stanowiła wielkie wyzwanie dla czytelników. Wydaje się, że to oni byli znacznie bardziej niż recenzenci otwarci na novum, kupując w ciągu dwóch tygodni 20 tysięcy egzemplarzy książki (Törnqvist 2016: 80). Pippi spotkała się z powszechną dość ostrą krytyką uderzającą w wywrotowy ton tekstu i „brzydkie” ilustracje (Törnqvist 2016: 83). Warto jednak zwrócić uwagę, że mimo wszystko zdarzały się też w prasie głosy pozytywne, a nawet jeden prorokujący kanoniczność tandemu Lindgren-Vang Nyman ${ }^{12}$.

Duńska artystka zwracała uwagę krytyków nie tylko pracowitością (w ciągu siedmiu lat była zaangażowana w realizację ok. trzydziestu książek, stale współpracowała z czasopismami, wykonywała także inne zlecenia projektowe), ale też wysokim poziomem technicznym swoich umiejętności, dbałością o przygotowanie rysunków i litografii do druku, świadomością możliwości wykorzystania poligrafii, która w latach 40. XX wieku była już w jej ojczyźnie bardzo dobrze rozwinięta. Godna podziwu wydaje się również gotowość Vang Nyman do pracy nad ilustracjami do książek o Pippi niejako wciąż od początku. W 1946 roku ukazał się drugi tom trylogii Pippi Långstrump går ombord (Pippi Pończoszanka wchodzi na pokład), w 1948 trzeci - Pippi Långstrump i Söderhavet (Pippi Pończoszanka na Południowym Pacyfiku), a w międzyczasie, czyli w 1947 roku, opublikowano pierwszą

12 Gattina (Gallie Åkarhielm), dziennikarka Morgon-Tidningen, porównała „spójność” tekstu i ilustracji w Pippi Långstrump do słynnego skandynawskiego duetu Hansa Christiana Andersena i Vilhelma Pedersena (Törnqvist 2016: 80). 
książkę obrazkową Känner du Pippi Långstrump? (Czy znasz Pippi Pończoszankę?) oraz ilustracje do opowiadanek zamieszczonych w popularnym magazynie Allers. Były one oparte na przygodach zawartych w pierwszej części trylogii. Drukowano także pojedyncze opowiadania, śpiewniki i foldery reklamowe. Artystka nie wykorzystywała swoich wcześniejszych rysunków jako szablonów - wymyślając nowe sceny i nowe ujęcia, po prostu wykonywała nowe ilustracje. Do Czy znasz Pippi Pończoszankę? powstało w 1947 roku pięćdziesiąt nowych ilustracji, a w 1952 roku, gdy ukazało się zbiorowe wydanie wszystkich trzech powieści, Vang Nyman wykonała sześć zupełnie nowych rozkładówek i własnoręcznie pokolorowała ilustracje (Törnqvist 2016: 162). W 1957 roku magazyn Klumpe Dumpe ${ }^{13}$ zaczął drukować paski komiksowe z przygodami wywrotowej ulubienicy dzieci. Odcinki ukazywały się w kolejnych numerach do września 1959 roku - roku śmierci ilustratorki.

Vang Nyman ilustrowanie dla dzieci traktowała z największą powagą, wierząc, że muszą one otrzymywać najlepszą sztukę i że ona jako świadoma swoich wysokich umiejętności artystka jest im w stanie taką sztukę zapewnić. Do wszystkich zleceń podchodziła $\mathrm{z}$ zapałem, wkładając $\mathrm{w}$ tworzone przez siebie ilustracje cały swój kunszt, umiejętności i oryginalny styl. W połowie lat 40. XX wieku nikt tak nie ilustrował książek dla dzieci ${ }^{14}$ - ani w Szwecji, ani w rodzinnej Danii. Co nie znaczy, że wśród artystów nie było takich, których interesowała i inspirowała zarazem ekspresja sztuki nieprofesjonalnej: prymitywnej, naiwnej, a także sztuki uprawianej przez same dzieci. Vang Nyman niewątpliwie należała do tej grupy. Jej postacie były wyraziste jak kontur, który je obrysowywał. W ilustracjach stworzonych przez Dunkę dominowały dynamiczne ujęcia scen i równie dynamiczne pozy przyjmowane przez małych bohaterów, z których każdy był świetnie uchwycony $\mathrm{z}$ charakteru, najczęściej dalekiego od tego pasującego do idealnego, posłusznego dziecka. Artystka umiejętnie rejestrowała zachowanie małoletnich, w którym odnajdziemy zarówno specyficzną nieporadność czy przejawy naśladowania dorosłych, jak i typową dla dzieci chęć zwrócenia na siebie uwagi.

Charakterystyczna dynamika scen w ilustracjach do książek o Pippi wynika także ze świadomie stosowanych przez artystkę zabiegów z perspektywą. O tym zjawisku pisze szerzej Elina Druker w swoim artykule zatytułowanym The animated still life. Ingrid Vang Nyman's use of self-contradictory spatial order in Pippi Longstocking (Druker 2007: 57-65). Szwedzka badaczka zauważa w ilustracjach Dunki dążenie do

13 Czasopismo założone w 1955 r. przez wydawnictwo Rabén \& Sjögren.

14 W tym kontekście dość interesująco wypada porównanie prac Vang Nyman z ilustracjami tworzonymi dekadę wcześniej w Polsce przez Franciszkę Themerson. Podobne u obu artystek operowanie wyraźnym konturem o zawadiackiej kresce, dynamiczne kompozycje często budowane na diagonali, zwariowane perspektywy, pusta umowna przestrzeń, specyficzna, niekanoniczna uroda bohaterów, by wymienić najbardziej charakterystyczne cechy, stanowią intrygujący materiał do analizy komparatystycznej i głębszych badań, które nie są przedmiotem tego artykułu. 
podważania naszego przyzwyczajenia dotyczącego logiki przedstawiania porządku przestrzennego. Vang Nyman wykorzystuje do tego różne środki, często używając perspektywy ukośnej, grając z perspektywą poprzez posługiwanie się odwróconymi ujęciami, nakładanie ich na siebie, stosując gwałtowne zmiany punktów widzenia, lekceważąc grawitację, zniekształcając i zaburzając proporcje, zapełniając, a raczej „Zabałaganiając” perspektywę licznymi obiektami (Druker 2007: 57-58). W efekcie artystka buduje w ten sposób przestrzeń, którą Druker określa jako wewnętrznie sprzeczną, paradoksalną, tętniącą nieustannym ruchem, zabawą i chaosem, czym podkreśla jej kompatybilność z osobowością i zachowaniem Pippi (il. 2).

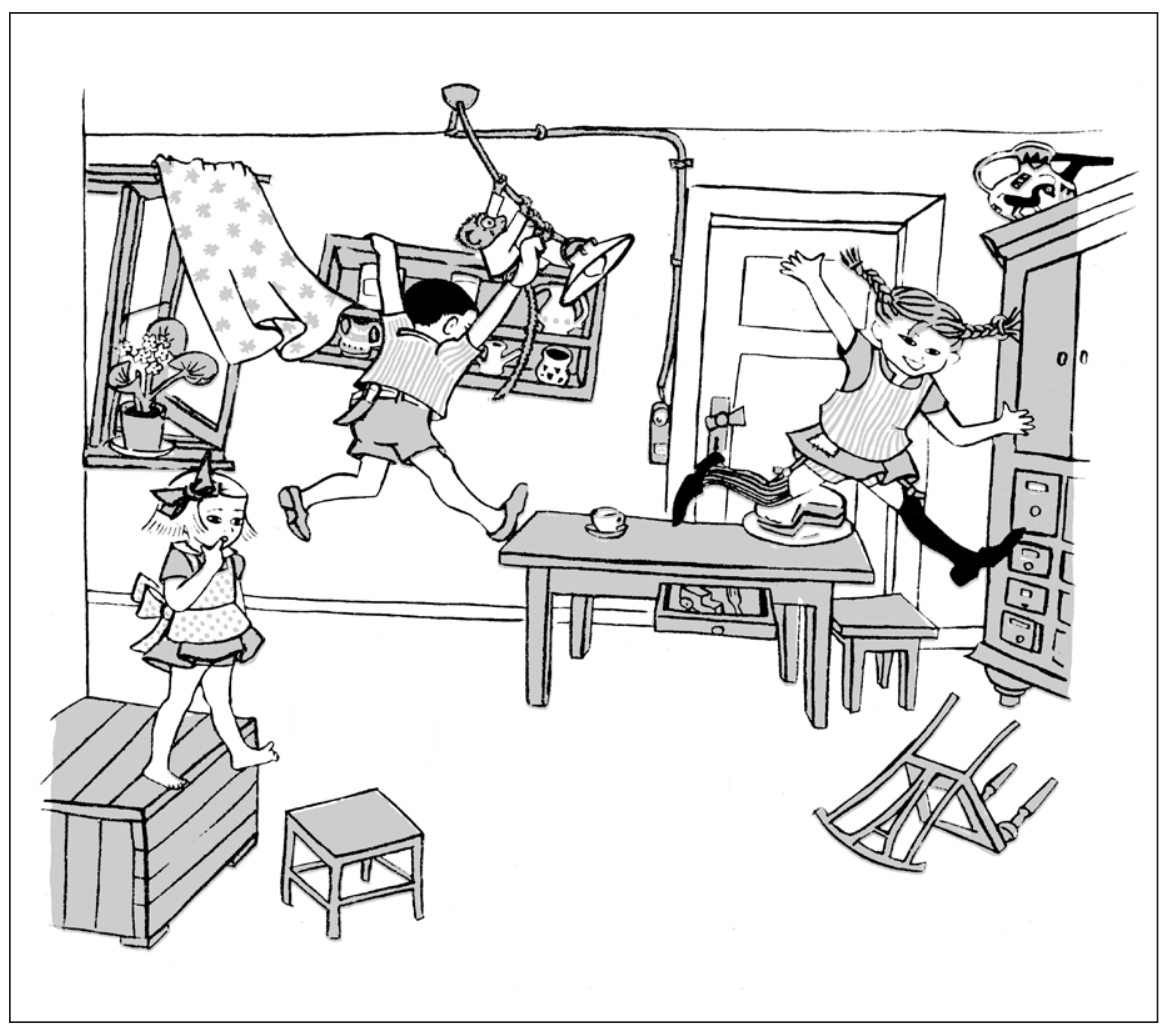

Ilustracja 2. Ilustracja zamieszczona w pierwszym wydaniu Pippi Långstrump wydawnictwa Rabén \& Sjögren. @Ingrid Vang Nyman, The Astrid Lindgren Company Źródło: Lindgren (1945).

To właśnie dominujący w ilustracjach Vang Nyman faktor zabawy badaczka uznaje za sprawcę tak silnej ekspresji, niezwykłej konstrukcji przestrzeni i powód ucieczki od klasycznej perspektywy linearnej. Z kolei o „przestrzennym zwrocie” dokonanym za sprawą nieszablonowej mieszkanki Willi Śmiesznotki pisze 
Mytych-Forajter (2016: 175-185). Talent ilustratorki w pełni pozwolił odzwierciedlić odwrócenie „obowiązujących dotychczas wektorów” (Mytych-Forajter 2016: 183).

Drugą charakterystyczną cechą ilustracji Vang Nyman jest ich specyficzna jakość estetyczna. Artystka umiejętnie żongluje wyrazistym konturem rysunku drobiazgowo oddającego zaobserwowane realia, swoiście odwołującym się do tradycji z przełomu XIX i XX wieku, oraz w pełni nowoczesnym sposobem wizualizowania. Jej postacie oraz elementy świata przedstawionego ocierają się o ekspresję twórców nieprofesjonalnych - dzieci, artystów ludowych czy reprezentujących sztukę naiwną - z ich niewprawnością w przedstawianiu stosunków przestrzennych (o czym była mowa wyżej), w zachowaniu proporcji czy w uchwyceniu szczegółów fizjonomii. Podobnie jak dzieci, Dunka powiększa swym bohaterom oczy i usta - to w nich zawiera się największy potencjał ekspresji, one sygnalizują temperaturę emocji i ich rodzaj. Co więcej, oczy postaci często zezują, usta przypominają upiorny uśmiech Jokera, a nos zostaje sprowadzony do dwóch dziurek, czyli dwóch czarnych kropek ${ }^{15}$, co skutkuje specyficzną brzydotą wynikającą też z kontrastu porządków: hiperestetyzującego (w stronę świadomego kiczu) przerostu formy i minimalistycznego schematyzmu. Ale i tu odnaleźć można głębokie uzasadnienie. Pippi była nie tylko najsilniejszym dzieckiem na świecie, ale i najbrzydszym, przynajmniej wedle słów wytwornego pana zainteresowanego kupnem Willi Śmiesznotki ${ }^{16}$. Twarze innych książkowych postaci niejednokrotnie ocierają się o karykaturę. Sylwetki bohaterów potrafią przyjmować najbardziej akrobatyczne pozy, by za chwilę sprawiać wrażenie zadziwiająco sztywnych, by nie rzec koślawych lub ukazanych w pozach przeczących zasadom anatomii. Dłonie dzieci ujęte są często sumarycznie, jedynie z zaznaczonymi sygnalnie pięcioma palcami, przypominając rysunki i malowidła naskalne z epoki kamienia. Podsumowaniem tych rozważań może być ilustracja o wymowie autotelicznej z pierwszego tomu trylogii, na której widzimy Pippi w trakcie pracy nad malowidłem (il. 3).

„Przedstawiało ono grubą panią w czerwonej sukni i w czarnym kapeluszu. W jednym ręku trzymała żółty kwiatek, a w drugim - zdechłą mysz. Było to, zdaniem Pippi, bardzo ładne malowidło. Ozdabiało cały pokój” (Lindgren 2017: 122). Oto i cudowna dychotomia: żółty kwiatek i zdechła mysz wydają się idealnie odwoływać do wspomnianego na początku tego akapitu kontrastu - między powszechnie akceptowalną estetyką a konotacjami kategorii abiektu. Pani ma zeza zbieżnego, słodkie usteczka i schematyczny kartofel nosa, suknię potraktowaną szkicowo, bez zbędnych szczegółów, za to starannie odmalowane nad wyraz fikuśne pantofle na obcasie i szykowny, trochę za duży, prawie napoleoński kapelusz. Zdecydowanie nie jest to arcydzieło, ale przecież... „bardzo ładne malowidło”.

15 Kto w dzieciństwie nie rysował w ten sposób nosa, niech pierwszy rzuci ołówkiem.

16 „- Wiesz co, jesteś - słowo daję - najbrzydszym dzieckiem, jakie kiedykolwiek widziałem” (Lindgren 2016a: 14). 


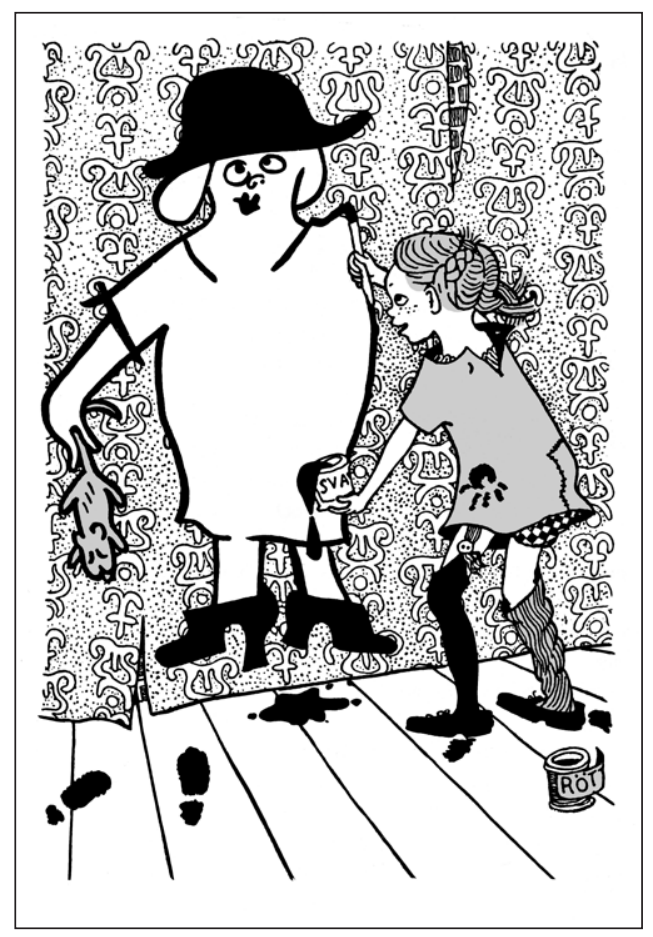

Ilustracja 3. Ilustracja zamieszczona w pierwszym wydaniu Pippi Långstrump wydawnictwa Rabén \& Sjögren. CIngrid Vang Nyman, The Astrid Lindgren Company Źródło: Lindgren (1945).

Vang Nyman po raz kolejny wskazuje, jak ważnym źródłem inspiracji był tekst książki. To świat przedstawiony według Pippi. Świat przedstawiony ma oddawać charakter, usposobienie i zachowanie głównej bohaterki. Nieszablonowość, rebeliancka niepoprawność Pippi jest przełożona na równie niepoprawne ilustracje, w których swój talent i techniczną biegłość artystka wykorzystała do stworzenia świata na opak, na pozór dającego się rozpoznać i oswoić, a jednak na swój sposób niemożliwego.

Trzecią poruszoną tu kwestią jest operowanie kolorem. Pierwsze wydanie trylogii o Pippi zawierało ilustracje czarno-białe, w późniejszych pojawił się jeden kolor - mocno przygaszony oranż. Kolor w pełni został po raz pierwszy użyty w książce obrazkowej Känner du Pippi Långstrump?, a potem także w komiksach. Vang Nyman wydaje się czynić użytek z koloru kojarzonego z esencją modernizmu, pierwszeństwo oddając trzem barwom podstawowym ${ }^{17}$ (il. 4).

\footnotetext{
17 Mam tu na myśli dyscyplinę kolorystyczną członków grupy De Stijl - malarstwa Pieta Mondriana i Theo van Doesburga w okresie neoplastycznym czy użycie barw podstawowych w projektach mebli Gerrita Rietvelda.
} 


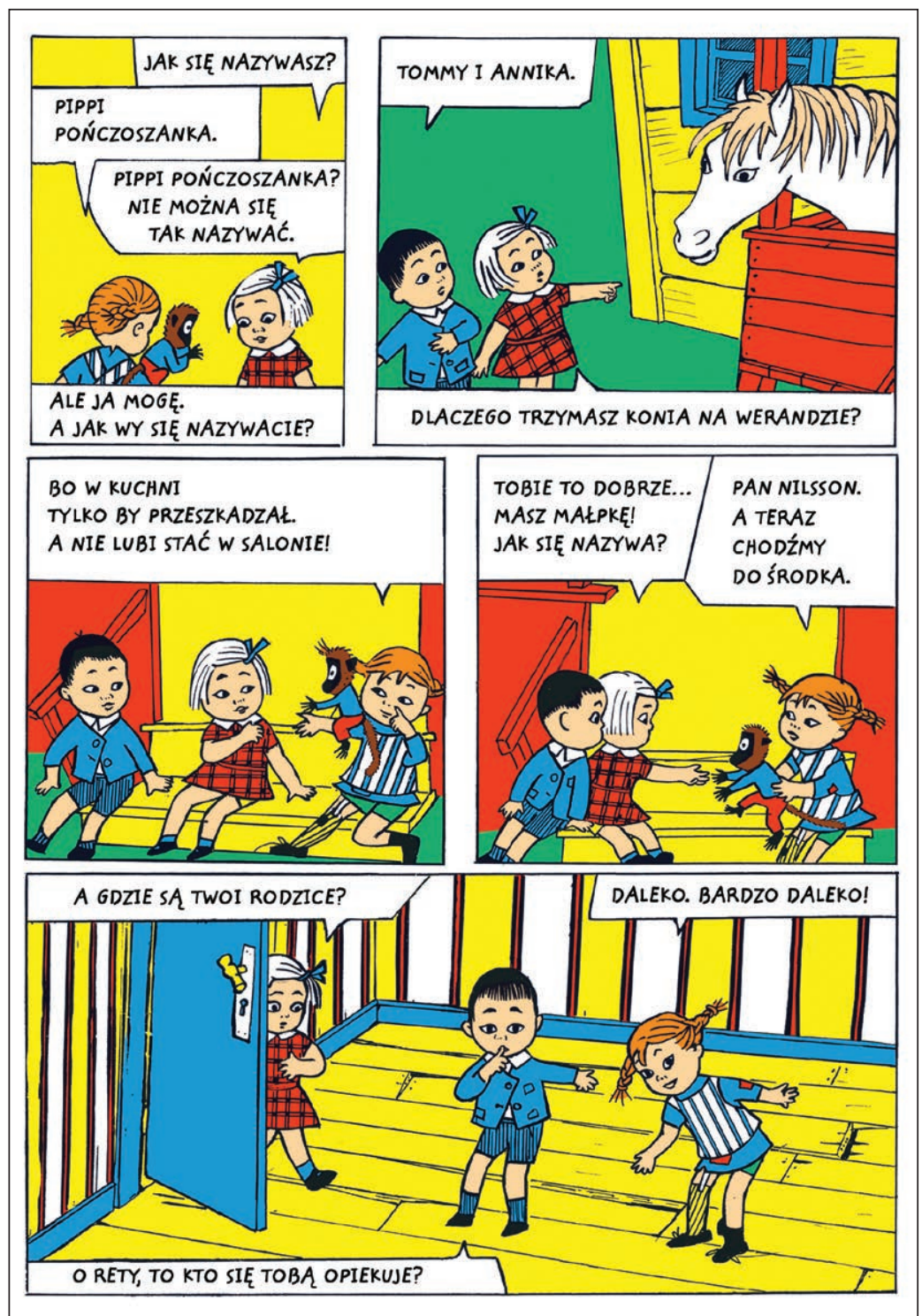

Ilustracja 4. Ilustracja zamieszczona w polskim wydaniu Pippi się wprowadza i inne komiksy Wydawnictwa Zakamarki

Źródło: Lindgren i Vang Nyman (2015).

Towarzyszące im zieleń i brąz oraz achromatyczne biel i czerń wydają się pełnić funkcje zdecydowanie drugoplanowe. Kolory są kładzione idealnie płasko, w dużym nasyceniu, ale dzięki zdyscyplinowanemu zawężeniu gamy i rezygnacji z jakiegokolwiek modelunku światłocieniowego gwarantują atrakcyjne wizualnie ilustracje, w których nadmiar zabiegów technicznych nie zaburza czytelności. 
Kolorem rządzącym w świecie Pippi jest niewątpliwie żółty. Jego zastosowanie jest uniwersalne - zgodnie i zupełnie niezgodnie z rzeczywistością, a przynajmniej z naszymi przyzwyczajeniami. O ile elewacje Willi Śmiesznotki, ściany szkoły, pokojów i podłogi Pippi, umownie potraktowane pole, złote monety, banany czy ser nie dziwią wcale, o tyle równie intensywnie żółte niebo, koń w cyrku lub mało maskująca złodziejska marynarka pochodzą już z alternatywnego świata wesołego rudzielca. Känner du Pippi Långstrump? była pod tym względem swoistym etapem przejściowym - pusta umowna przestrzeń w niektórych ilustracjach nabrała żółtego koloru (il. 5), który jako tło i budulec świata przedstawionego króluje już niepodzielnie w komiksach.

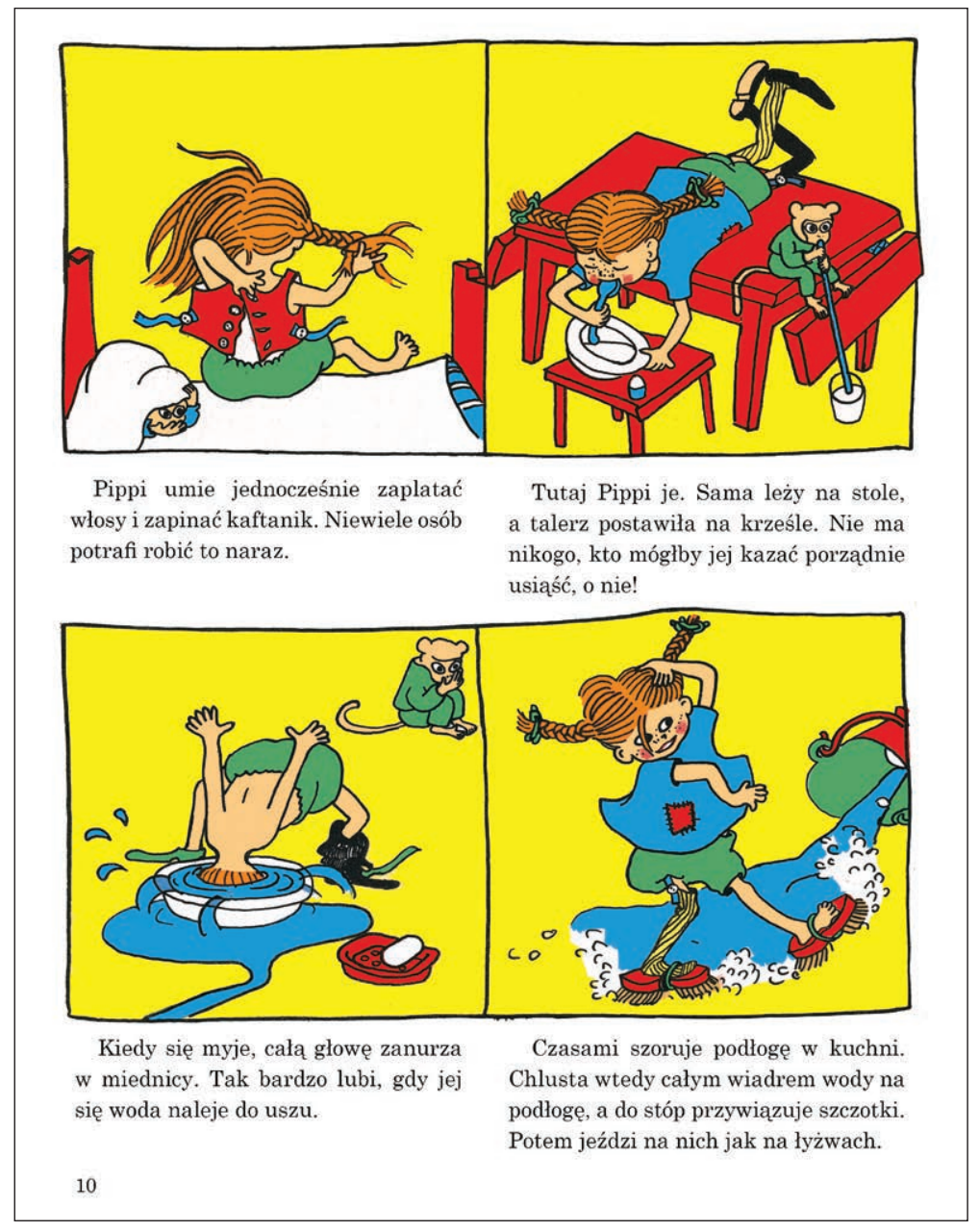

Ilustracja 5. Ilustracja zamieszczona w polskim wydaniu Czy znasz Pippi Pończoszankę? Wydawnictwa Zakamarki Źródło: Lindgren i Vang Nyman (2007). 
Pierwsza książka obrazkowa o Pippi wprowadziła też ramki dla pojedynczych ilustracji - oczywiste morfologicznie w komiksie, a zupełnie nieobecne w ilustracjach do trylogii powieściowej.

Bezsprzecznym osiągnięciem Ingrid Vang Nyman była umiejętność twórczego podążania za zdobyczami sztuki nowoczesnej. Artystka z sukcesem wykorzystywała nowe sposoby analizowania struktur wizualnych i nieklasyczne podejście do przestrzeni, wywodzące się nie tylko z awangardowych poszukiwań kubistów czy rewolucji neoplastycznej, ale i z powszechnej wówczas fascynacji sztuką dalekowschodnią. $Z$ jednej strony była więc modernistką, z drugiej zaś bardzo dorośle traktowała dziecięcego czytelnika, dla którego, jak uważała, warto było, a zatem należało stworzyć dzieło najwyższej jakości artystycznej idące pod prąd tradycji śmiałe pod względem formalnym, odważne w treści, a nade wszystko idealnie współgrające $\mathrm{z}$ materią tekstu.

\section{Podziękowania}

Autorka pragnie serdecznie podziękować Agnieszce Stróżyk za cenne uwagi i pomoc w tłumaczeniu tytułów publikacji, Krzysztofowi Szczurkowi za pomoc w tłumaczeniu biografii Ingrid Vang Nyman oraz Katarzynie Skalskiej za ważne uściślenia i wszechstronną pomoc. Tack så mycket!

\section{Bibliografia}

Literatura podmiotu

Lindgren, A. (1944). Britt-Mari lättar sitt hjärta [Zwierzenia Britt-Mari]. Stockholm: Rabén \& Sjögren.

Lindgren, A. (1945). Pippi Långstrump [Pippi Pończoszanka]. Stockholm: Rabén \& Sjögren.

Lindgren, A. (1946). Pippi Långstrump går ombord [Pippi Pończoszanka wchodzi na pokład]. Stockholm: Rabén \& Sjögren.

Lindgren, A. (1948). Pippi Långstrump i Söderhavet [Pippi Pończoszanka na Południowym Pacyfiku]. Stockholm: Rabén \& Sjögren.

Lindgren, A. (1957). Dzieci z Bullerbyn. Il. H. Czajkowska. Tłum. I. Szuch-Wyszomirska. Warszawa: Nasza Księgarnia.

Lindgren, A. (1958). Nils Paluszek. Il. H. Czajkowska. Tłum. I. Szuch-Wyszomirska. Warszawa: Nasza Księgarnia.

Lindgren, A. (1959a). Karlsson z dachu. Il. H. Czajkowska. Tłum. I. Szuch-Wyszomirska. Warszawa: Nasza Księgarnia.

Lindgren, A. (1959b). Rasmus i włóczęga. Il. M. Orłowska-Gabryś. Tłum. I. Szuch-Wyszomirska. Warszawa: Nasza Księgarnia.

Lindgren, A. (1961). Fizia Pończoszanka. Il. Z. Piotrowski. Tłum. I. Szuch-Wyszomirska. Warszawa: Nasza Księgarnia. 
Lindgren, A. (1962). Zwierzenia Britt-Mari. Il. L. Janecka. Tłum. I. Szuch-Wyszomirska. Warszawa: Nasza Księgarnia.

Lindgren, A. (1984a). Fizia Pończoszanka na Południowym Pacyfiku. Il. A. Kołakowska. Tłum. T. Chłapowska. Warszawa: Nasza Księgarnia.

Lindgren, A. (1984b). Fizia Pończoszanka wchodzi na pokład. Il. A. Kołakowska. Tłum. T. Chłapowska. Warszawa: Nasza Księgarnia.

Lindgren, A. (1992). Zabawa choinkowa Pippi. Tłum. A. Węgleńska. Warszawa: Nasza Księgarnia.

Lindgren, A. (2007). Czy znasz Pippi Pończoszankę? Il. I. Vang Nyman. Tłum. A. Węgleńska. Poznań: Zakamarki.

Lindgren, A. (2008). Pippi na wyspie Kurrekurredutt. Il. I. Vang Nyman. Tłum. A. Węgleńska. Poznań: Zakamarki.

Lindgren, A. (2015). Pippi Pończoszanka. Il. Z. Piotrowski. Tłum. I. Szuch-Wyszomirska. Warszawa: Nasza Księgarnia.

Lindgren, A. (2016a). Pippi Pończoszanka na Południowym Pacyfiku. Il. I. Vang Nyman. Tłum. T. Chłapowska. Warszawa: Nasza Księgarnia.

Lindgren, A. (2016b). Pippi Pończoszanka wchodzi na pokład. Il. I. Vang Nyman. Tłum. T. Chłapowska. Warszawa: Nasza Księgarnia.

Lindgren, A. (2017). Pippi Pończoszanka. Il. I. Vang Nyman. Tłum. I. Szuch-Wyszomirska. Warszawa: Nasza Księgarnia.

Lindgren, A. i I. Vang Nyman. (1947). Känner du Pippi Långstrump? [Czy znasz Pippi Pończoszankę?]. Stockholm: Rabén \& Sjögren.

Lindgren, A. i I. Vang Nyman. (1993a). Pippi jest najsilniejsza na świecie. Tłum. A. Węgleńska. Warszawa: Nasza Księgarnia.

Lindgren, A. i I. Vang Nyman. (1993b). Pippi urządza przyjęcie. Tłum. A. Węgleńska. Warszawa: Nasza Księgarnia.

Lindgren, A. i I. Vang Nyman. (2015). Pippi się wprowadza i inne komiksy. Tłum. A. Węgleńska. Poznań: Zakamarki.

Lindgren, A. i I. Vang Nyman. (2016). Pippi zawsze sobie poradzi i inne komiksy. Tłum. A. Węgleńska. Poznań: Zakamarki.

Lindgren, A i I. Vang Nyman. (2020). Pippi w parku. Tłum. A. Węgleńska. Poznań: Zakamarki.

\section{Literatura przedmiotu}

Barnens önskebok. (1945). [Dziecięca księga życzeń]. Stockholm: Lindqvist.

Bąk, K. (1986). Piszę dla dziecka, którym byłam. Z Astrid Lindgren rozmowa druga. Nowe Książki 2: 1-6.

Druker, E. (2007). The animated still life. Ingrid Vang Nyman's use of self-contradictory spatial order in Pippi Longstocking. Barnboken. Journal of Children's Literature Research 30 (1-2): 57-65. DOI: https://doi.org/10.14811/clr.v30i1-2.48.

Druker, E. (2013). En Dansk förbindelse: den moderna bilderbokens födelse. W: Berg, A. i S. Teleman (red.). Svensk illustration - en visuell historia 1900-2000. Malmö: Arenas, s. 102-115.

Dymel-Trzebiatowska, H. (2018). Känner du Pippi Långstrump? (1947). W: M. Cackowska, H. Dymel-Trzebiatowska i J. Szyłak (red.). Książka obrazkowa. Leksykon. T. 1. Poznań: Instytut Kultury Popularnej, s. 203-207.

Dymel-Trzebiatowska, H. i E. Mrozek-Sadowska (red.). (2008). Astrid Lindgren - 100 lat. Interpretacje. Gdańsk: Pressfabryka.

Freuchen, P. (1945). Ivik den faderlöse [Ivik, chłopiec bez ojca]. Stockholm: Gebers. 
Gaare, J. i Ø. Sjaastad. (2002). Pippi i Sokrates. Filozoficzne wędrówki po świecie Astrid Lindgren. Tłum. I. Zimnicka. Warszawa: Jacek Santorski \& Co.

Gralewicz-Wolny, I. i B. Mytych-Forajter. (2013). Uwolnić Pippi! Twórczość dla dzieci wobec przemian kultury. Katowice: Wydawnictwo Uniwersytetu Śląskiego.

Hallberg, K. (2001). Ingrid Vang Nyman har tegnet meget andet end Pippi. W: T. Nielsen (red.). Pippi Langstrømpe og meget, meget mere. Vorker af den danske kunstner Ingrid Vang $\mathrm{Ny}$ man. Vejen: Vejen Kunstmuseum, s. 26-44.

Kümmerling-Meibauer, B. i A. Surmatz (red.). (2011). Beyond Pippi Longstocking. Intermedial and international aspects of Astrid Lindgren's works. New York: Routledge.

Lundqvist, U. (1998). Pippi Langstrump - na zawsze. W: M. Hempowicz (red.). Astrid Lindgren - Barwy świata dzieciństwa. Materiały z sesji literackiej. Gdańsk: Nadbałtyckie Centrum Kultury.

Murzynowska, D. (2007). Pippi Pończoszanka w polskim dyskursie kulturowym / Pippi Longstocking in the Polish cultural discourse. Praca magisterska, Sztokholm: Uniwersytet Sztokholmski, http://www.diva-portal.org/smash/get/diva2:197270/FULLTEXT01.pdf (dostęp: 6.04.2020).

Mytych-Forajter, B. (2016). Rude słońce. Przygody Pippi Astrid Lindgren i przestrzenna rewolucja. W: W. Kostecka i M. Skowera (red.). Geografia krain zmyślonych. Wokół kategorii miejsca i przestrzeni $w$ literaturze dziecięcej, młodzieżowej i fantastycznej. Warszawa: Wydawnictwo Stowarzyszenia Bibliotekarzy Polskich, s. 175-185.

Podsiadło, J. (2006). Pippi, dziwne dziecko. Warszawa: Hokus-Pokus.

Rehdin, U. i G. Grähs (red.). (2016). Vår Pippi - Vår Vang. Tecknarna hyllar Ingrid Vang Nyman och det moderna genombrottet inom svensk barnboksbild. Stockholm: Salikon förlag.

Rogoż, M. (2010). Wizerunek Astrid Lindgren w polskiej prasie. Acta Universitatis Lodziensis. Folia Librorum 16: 285-302.

Shevah, E. (2015). Pippi Longstocking: a feminist, an optimist and a free thinker. The Guardian, 9 września 2015. https://www.theguardian.com/childrens-books-site/2015/sep/09/pippilongstocking-a-feminist-an-optimist-and-a-free-thinker (dostęp: 6.04.2020).

Söderberg, E. (2010). After Pippi Longstocking. On Gender in Children's Literature, School, and Culture in Sweden. Cahiers du Genre 2 (49): 77-96.

Strömstedt, M. (2000). Astrid Lindgren. Opowieść o życiu i twórczości. Tłum. A. Węgleńska. Warszawa: Nasza Księgarnia.

Teodorowicz-Hellman, E. (1997). „Fizia Pończoszanka” w tłumaczeniu polskim. O przekładzie literatury dla dzieci i młodzieży. W: P. Fast (red.). Obyczajowość a przekład. Katowice: Wydawnictwo „Śląsk”, s. 131-146.

Törnqvist, L. (2016). Ingrid Vang Nyman. Stockholm: Salikon förlag.

Tylicka B. i G. Leszczyński (red.). (2002). Słownik literatury dziecięcej i młodzieżowej. WrocławWarszawa-Kraków: Ossolineum.

Wincencjusz-Patyna, A. (2011). Nie tylko Muminki, czyli to i owo o skandynawskiej ilustracji dla dzieci. Quart. Kwartalnik Instytutu Historii Sztuki Uniwersytetu Wrocławskiego 2 (20): $62-85$.

Filmografia

Pippi Langstrumpf (Pippi Långstrump). (1969). [serial przygodowy]. Reżyseria: O. Hellbom. Szwecja, RFN: Beta Film, Hessischer Rundfunk (HR), Iduna Film Produktiongesellschaft, Nord Art, Svensk Filmindustri (SF), Sveriges Radio. 